\title{
Relationship between Vitamin B9 (Folic Acid), Vitamin B12 (Cobalamin), and Peripheral Neuropathy in Children with Beta-Thalassemia Major
}

\author{
Uni Gamayani, ${ }^{1}$ Titin Junaidi, ${ }^{1}$ Nushrotul Lailiyya, ${ }^{1}$ Nur Suryawan, ${ }^{2}$ Nanan Sekarwana ${ }^{2}$ \\ ${ }^{1}$ Department of Neurology, Faculty of Medicine, Universitas Padjadjaran/Dr. Hasan Sadikin General Hospital, \\ Bandung, Indonesia, ${ }^{2}$ Department of Child Health, Faculty of Medicine, Universitas Padjadjaran/Dr. Hasan \\ Sadikin General Hospital, Bandung, Indonesia
}

\begin{abstract}
Vitamin B9 (folic acid) and B12 (cobalamin) are essential vitamins that play roles in the process of hematopoiesis and maintaining the function of peripheral nerves. Therefore, these deficiencies may create a risk for peripheral neuropathy in beta-thalassemia major patients. The purpose of this study is to determine the relationship between vitamin B9 level, vitamin B12 level, and peripheral neuropathy in beta-thalassemia major children. It was an observational analytical study with a case-control design has been conducted at Dr. Hasan Sadikin General Hospital Bandung, Indonesia, in May-July 2019. There were 47 beta-thalassemia major children with peripheral neuropathy (case) and 41 healthy children (control). All subjects completed a general demographic questionnaire, underwent neurological examination, and were tested for vitamin B9 and B12 serum levels. Data were then analyzed using the unpaired t test to compare the vitamin levels between both groups and Spearman's rank correlation test to investigate the correlation between vitamin levels and the number of affected nerves in the case group. Comparison of folic acid levels in the case group $(21.52 \pm 6.22 \mathrm{ng} / \mathrm{mL})$ and the control group $(23.81 \pm 7.51 \mathrm{ng} / \mathrm{mL})$ showed no significant difference $(\mathrm{p}=0.19)$. In contrast, cobalamin in the case group $(288.57 \pm 168.61 \mathrm{ng} / \mathrm{mL})$ and the control group (385.95 $\pm 197.48 \mathrm{ng} / \mathrm{mL}$ ) showed a significant difference $(\mathrm{p}=0.01)$. In addition, there was a moderate correlation $(\mathrm{p}=0.004, \mathrm{r}=0.41)$ between folic acid level and the number of motoric nerves affected in the case group. In conclusion, cobalamin level correlates with peripheral neuropathy in beta-thalassemia major patients, and folic acid level correlates with the number of affected nerves, especially motoric nerves.
\end{abstract}

Keywords: Cobalamin, folate, peripheral neuropathy, thalassemia

\section{Hubungan antara Vitamin B9 (Asam Folat), Vitamin B12 (Kobalamin), dan Neuropati Perifer pada Anak dengan Talasemia Beta Mayor}

\begin{abstract}
Abstrak
Vitamin B9 (asam folat) dan B12 (kobalamin) merupakan vitamin esensial yang berperan dalam proses hematopoesis dan menjaga fungsi saraf tepi. Defisiensi vitamin ini dapat menimbulkan risiko neuropati perifer pada pasien talasemia beta mayor. Tujuan penelitian ini mengetahui hubungan antara kadar vitamin B9, vitamin B12, dan neuropati perifer pada anak talasemia beta mayor. Metode penelitian ini adalah analitik observasional dengan rancangan studi kasus kontrol yang dilakukan di RSUP Dr. Hasan Sadikin Bandung, Indonesia pada MeiJuli 2019. Terdapat 47 anak talasemia beta mayor dengan neuropati perifer (kelompok kasus) dan 41 anak sehat (kelompok kontrol). Seluruh subjek penelitian mengisi kuesioner demografi umum, menjalani pemeriksaan fisis neurologis, serta dilakukan tes kadar vitamin B9 dan B12 serum. Uji t test tidak berpasangan digunakan untuk membandingkan kadar vitamin pada kedua kelompok dan uji korelasi Spearman untuk membandingkan kadar kedua vitamin tersebut dengan jumlah saraf yang terkena pada kelompok kasus. Perbandingan kadar asam folat kelompok kasus $(21,52 \pm 6,22 \mathrm{ng} / \mathrm{mL})$ dengan kelompok kontrol $(23,81 \pm 7,51 \mathrm{ng} / \mathrm{mL})$ menunjukkan perbedaan yang tidak bermakna $(\mathrm{p}=0,19)$, sedangkan perbandingan kadar kobalamin kelompok kasus $(288,57 \pm 168,61 \mathrm{ng} / \mathrm{mL})$ dengan kelompok kontrol $(385,95 \pm 197,48 \mathrm{ng} / \mathrm{mL})$ menunjukkan perbedaan yang bermakna (p=0,01). Selain itu, terdapat korelasi sedang $(\mathrm{p}=0,004 ; \mathrm{r}=0,41)$ antara kadar asam folat dan jumlah saraf motorik yang terkena pada kelompok kasus. Kesimpulan, kadar kobalamin berhubungan dengan neuropati perifer pada penderita talasemia beta mayor dan kadar asam folat berhubungan dengan jumlah saraf yang terkena, terutama saraf motorik.
\end{abstract}

Kata kunci: Folat, kobalamin, neuropati perifer, talasemia 


\section{Introduction}

Vitamin B, especially are vitamin B1 (thiamine), B6 (pyridoxine), B9 (folic acid), and $\mathrm{B} 12$ (cobalamin), has the function of maintaining the development and integrity of the nervous system, especially the peripheral nervous system..$^{1,2}$ Thalassemia is a hereditary blood disorder in the form of impaired synthesis of alpha or betaglobin chains, with beta-thalassemia major as the most severe clinical form. ${ }^{3}$ Indonesia is one of the countries included in the thalassemia areas, with the number of carriers reaching $5-10 \%$. West Java, as the most populated province in Indonesia, currently has approximately 445 people with beta-thalassemia. ${ }^{4,5}$

The life expectancy of people with thalassemia increases with the availability of routine blood transfusions and iron chelation therapy. It also means that the possibility that they experience complications also increases. Neurological complications experienced by these patients may affect central and peripheral nerves. Several neurological disorders have been reported in the peripheral nervous system, one of which is peripheral neuropathy. ${ }^{6,7}$

Peripheral neuropathy is a neurological complication with a reasonably high incidence with symptoms often missed by the patients, especially in younger patients. It is not included in one of the focuses in the management of children with thalassemia. ${ }^{7}$ With age, peripheral neuropathy symptoms will worsen and interfere with daily activities, thus reducing the quality of life of the patients, especially when accompanied by neuropathic pain. Therefore, it is necessary to evaluate peripheral nerves in thalassemia patients to provide appropriate interventions to maintain the quality of life of people with thalassemia. ${ }^{8}$ Nerve conduction study, or NCS, is an electrophysiological examination that can detect disorders of the peripheral nerves, both in motor and sensory nerves, and helps to establish the diagnosis of peripheral neuropathy. This type of examination is necessary because peripheral neuropathy is often subclinical. Abnormal NCS images can also be found in people who have not shown symptoms and or signs of neuropathy, making it useful for early detection of peripheral nerve disorders in patients with beta-thalassemia major. ${ }^{6}$

Peripheral neuropathy in people with thalassemia can be caused by various etiologies, including anemia, high ferritin level, and vitamin B deficiency. In 2015, there were 447 children with beta-thalassemia major undergoing blood transfusions at the Thalassemia Clinic of Dr. Hasan Sadikin General Hospital Bandung, Indonesia. Dewi et al. ${ }^{9}$ in 2017 and Gamayani et al. $^{10}$ in 2019 investigated the incidence of peripheral neuropathy in thalassemia patients treated at Dr. Hasan Sadikin General Hospital. Dewi et al. ${ }^{9}$ studied 50 beta-thalassemia major patients aged 8-14 years and discovered that hemoglobin and ferritin levels are linked to 98 percent of peripheral neuropathy features in the Nerve Conduction Study (NCS). In 2019, Gamayani et al..$^{10}$ showed that persistent anemia and iron deposition are related to a significant peripheral neuropathy prevalence in adult patients. However, those previous studies did not examine cobalamin and folic acid levels, that those levels were unknown in their study subjects. Based on the description of the background above, the purpose of this study is to determine the relationship between vitamin B9 (folic acid), vitamin B12 (cobalamin), and peripheral neuropathy in beta-thalassemia major children.

\section{Methods}

This study used a case-control approach to study children with beta-thalassemia major presented to the Pediatric Thalassemia Clinic of Dr. Hasan Sadikin General Hospital Bandung, Indonesia, who met the inclusion and exclusion criteria. Subjects included were children aged 8-18 years, diagnosed with peripheral neuropathy based on NCS examination, had a mean pre-transfusion $\mathrm{Hb}$ level of $<10 \mathrm{~g} / \mathrm{dL}$ with a mean serum ferritin level of $1,000 \mu \mathrm{g} / \mathrm{L}$ in the last six months, had normal nutritional status according to the WHO's body mass index, and children and parents were willing to participate in the study.

Subjects in the control group were of the same age as the subjects in the case group. However, they were not diagnosed with peripheral neuropathy based on anamnesis and physical examination and had hemoglobin and ferritin levels within normal limits. Exclusion criteria for both case and control groups were the presence of hearing loss, visual disturbances, neurological deficits leading to suspicion of an intracranial lesion. In addition, they had a history of chronic infectious disease, had a history of autoimmune disease or malignancy, and had a history of using 
drugs that cause peripheral neuropathy such as chemotherapy agents (vincristine) or tuberculosis drugs (isoniazid). This study was performed from May to August 2019 and approved by the Universitas Padjadjaran Research Ethics Committee through the issuance of ethical clearance number: 588/UN6.KEP/EC/2019.

Data on the characteristics of the subjects were obtained from medical records, anamnesis, physical and laboratory examinations, and NCS examination results from the neurophysiology laboratory of the hospital. Data collected were then processed using SPSS for Windows version 24.00. Both groups were tested using the unpaired $\mathrm{t}$ test to compare the vitamin levels between both groups and Spearman's rank correlation test to investigate the correlation between vitamin levels and the number of affected nerves in the case group. The relationship was considered significant if the $\mathrm{p}$ value was $\leq 0.05$.

\section{Results}

Forty-seven children were included in this study as the case subjects with characteristics as listed in Table 1. Sensory symptoms resulting from history taking were reported in five individuals (11\%) and included numbness, discomfort, and tingling. There were no motor complaints found. Four participants (7\%) had sensory impairments in the form of glove and stocking hypesthesia, as determined by neurological testing. There was no evidence of a motor deficiency, on the other hand. In eight patients, physiological responses were found to be reduced (17\%).

Table 1 presents the description of the characteristics of the case group subjects based on age, gender, motor and sensory symptoms, and the number of affected nerves based on NCS examination. The mean age of the case group was $13.27 \pm 1.79$ years, with more or less equal gender distribution between males and females. Based on the previous NCS examination, the average number of sensory nerves affected from the six nerves examined was $1.44 \pm 1.79$. In comparison, examination on eight motor nerves demonstrated that more than $3.04 \pm 1.81$ nerves were affected.

The control group in this study consisted of 41 healthy children. The comparison of the characteristics between the case and control groups is listed in Table 2. Table 2 describes the comparison between the characteristics of the

\section{Table 1 Case Group Characteristics}

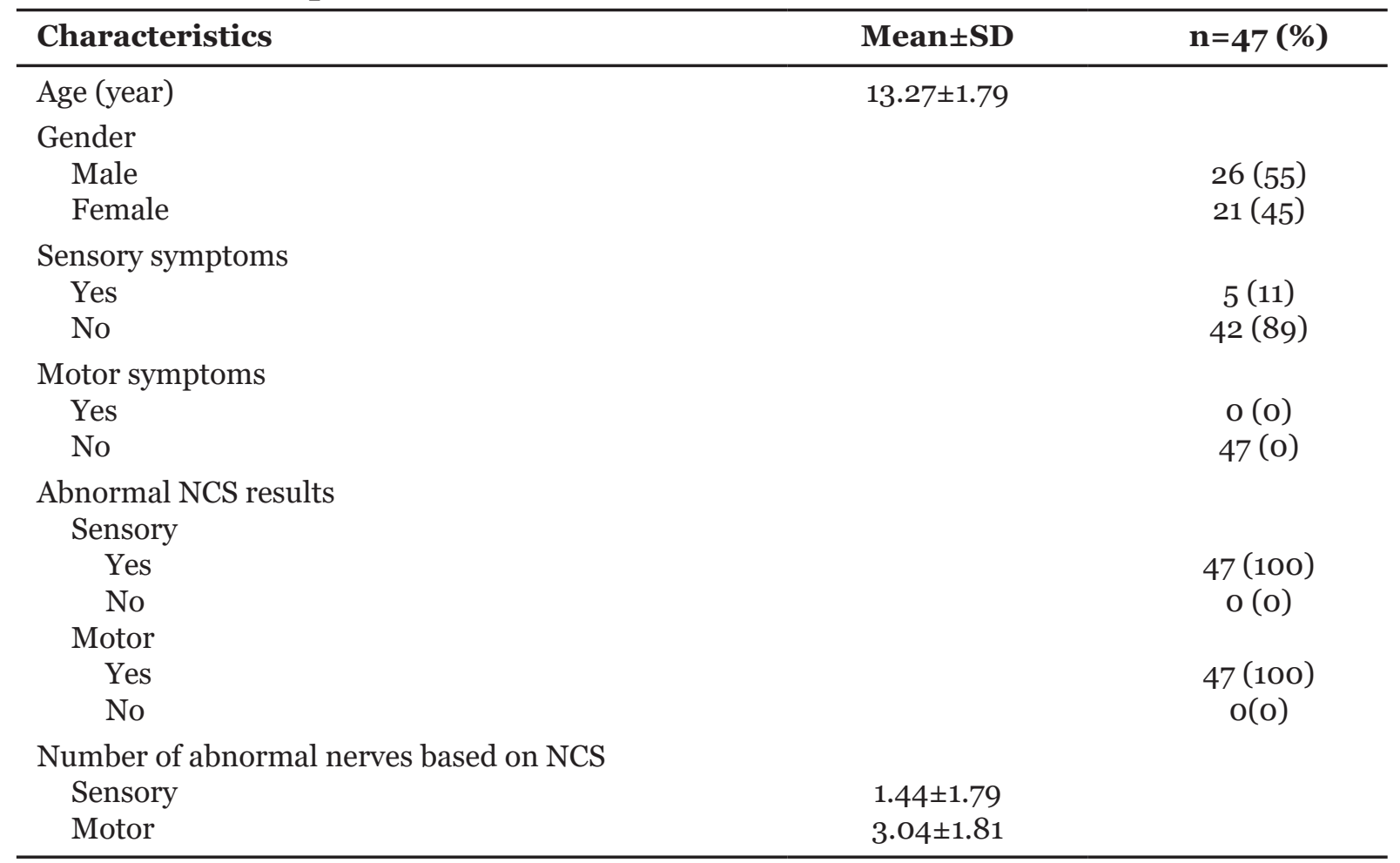


Table 2 Comparison of Case and Control Group Characteristics

\begin{tabular}{|c|c|c|c|}
\hline Characteristics & $\operatorname{Case}(n=47)$ & Control $(n=41)$ & $\overline{\text { p Value }}$ \\
\hline $\begin{array}{l}\text { Age (year) } \\
\text { Mean } \pm \text { SD } \\
\text { Median } \\
\text { Range (min-max) }\end{array}$ & $\begin{array}{c}13.27 \pm 1.79 \\
13.00 \\
10.00-17.00\end{array}$ & $\begin{array}{c}13.19 \pm 1.77 \\
13.00 \\
11.00-18.00\end{array}$ & 0.710 \\
\hline $\begin{array}{l}\text { Gender } \\
\text { Male } \\
\text { Female }\end{array}$ & $\begin{array}{l}26(55 \%) \\
21(45 \%)\end{array}$ & $\begin{array}{l}23(56 \%) \\
18(44 \%)\end{array}$ & 0.940 \\
\hline $\begin{array}{l}\text { Folic acid/vitamin B9 levels (ng/mL) } \\
\text { Mean } \pm \text { SD } \\
\text { Median } \\
\text { Range (min-max }\end{array}$ & $\begin{array}{c}21.52 \pm 6.22 \\
20.70 \\
11.90-41.50\end{array}$ & $\begin{array}{c}23.81 \pm 7.51 \\
21.90 \\
12.50-43.30\end{array}$ & 0.190 \\
\hline $\begin{array}{l}\text { Cobalamin/vitamin B12 levels (ng/mL) } \\
\text { Mean } \pm \text { SD } \\
\text { Median } \\
\text { Range (min-max) }\end{array}$ & $\begin{array}{c}288.57 \pm 168.61 \\
252.60 \\
98.40-792.40\end{array}$ & $\begin{array}{c}385.95 \pm 197.48 \\
324.20 \\
100.10-871.30\end{array}$ & $0.010^{*}$ \\
\hline
\end{tabular}

case and control groups based on age, sex, folic acid levels, and cobalamin levels. There was no significant difference in age, sex, and folic acid levels between the two groups. In contrast, a significant difference was seen in the cobalamin level.

Table 3 demonstrates that there was a significant correlation between the folic acid level and the number of motor nerves affected. Table 4 demonstrates that there was no correlation between cobalamin level and the number of nerves affected.

\section{Discussion}

Subjects of this study were 8-18 years old, making it possible to do accurate anamnesis and neurological examination. No significant differences in gender, age, and BMI between case and control subjects were found; hence, the two groups were deemed comparable.

A ferritin level serum of $>1,000 \mathrm{~g} / \mathrm{L}$ and $\mathrm{Hb}<10 \mathrm{~g} / \mathrm{dL}$ are considered the most common factors that cause long-term complications in thalassemia patients undergoing regular

Table 3 Correlation between Folic Acid Level and Number of Affected Sensory and Motor Nerves based on NCS in Case Group

\begin{tabular}{lccc}
\hline Variables & Correlation & R & p Value \\
\hline Folic acid level and number of sensory nerves affected & Spearman & 0.157 & 0.293 \\
Folic acid level and number of motor nerves affected & Spearman & 0.41 & 0.004 \\
\hline
\end{tabular}

Table 4 Correlation between Cobalamin Level and Number of Affected Sensory and Motor Nerves based on NCS in Case Group

\begin{tabular}{lccc}
\hline Variables & Correlation & R & p Value \\
\hline $\begin{array}{l}\text { Correlation between cobalamin and number of sensory } \\
\text { nerves affected }\end{array}$ & Spearman & 0.237 & 0.109 \\
$\begin{array}{l}\text { Correlation between cobalamin and number of motor } \\
\text { nerves affected }\end{array}$ & Spearman & 0.137 & 0.359 \\
\hline
\end{tabular}


transfusion and iron chelation treatment. ${ }^{11}$ Peripheral neuropathy is one of the complications that can occur in this condition. ${ }^{12}$ Decreased folic acid and cobalamin levels can be observed due to increased demand or high degradation of ferritin, which may become one of the causes of peripheral neuropathy. ${ }^{13-15}$

Vitamins B1, B6, folate, and B12 are micronutrients known to play essential roles in maintaining peripheral nerves. The mechanism of action of these vitamins is closely related, especially between folate and B12. These two vitamins should be examined simultaneously because they are related to the "remethylation pathway" process. Vitamin B12 is needed by the body to convert N5-methylene THF to THF. If there is a vitamin B12 deficiency, THF will be trapped in the form of N5-methylene THF, or known as "folate trapping," which causes folate deficiency. ${ }^{16}$ In this study, the levels of other B vitamins were not examined; thus, they become the confounding factor in the study. ${ }^{2,16}$

Folic acid levels were within normal limits among subjects in the case group of this study. There was no case of folic acid deficiency, and no significant difference was identified in folic acid levels between the case and control groups. It is different from the study by Patil and Mujawar ${ }^{17}$ on 30 thalassemia patients and Asma et al. ${ }^{18}$ on 145 thalassemia patients. In Asma et al..$^{18}$ study, the folic acid deficiency was seen in $10.3 \%$ of the subjects. This difference may be because the case group subjects in our study had taken folic acid supplements for a period of 3 to 14 years at a dose of 3 to 5 tablets/day or 3 to $5 \mathrm{mg} /$ day with good adherence, while this is not clear in the study of Asma et al. ${ }^{18}$

Serum folic acid level examination is performed as an initial screening when deficiency is suspected; however, it does not reflect the longterm folic acid status. Folic acid concentration will increase five times from the normal value after four hours of oral intake of $1.6 \mathrm{mg}$ folic acid supplement. In addition, serum folic acid levels can also be used as a marker of supplement intake. ${ }^{19}$ This study selected serum folic acid to be examined because it is easier and more efficient to work in bulk when compared to the red blood cell folic acid. There was a significant difference in cobalamin level between the case and control group, but the levels in both groups were still within normal limits.

This study found a significant relationship between folic acid level and the number of motor nerves affected. The higher the folic acid level was, the lesser the number of motor nerves affected. This follows the findings of Kang et al. ${ }^{20}$ stated that folic acid has a neurotrophic effect on myelin differentiation, proliferation, and repair by regulating the methylation process of deoxyribonucleic acid (DNA) in specific genes. It increases Schwann cells proliferation and migration and secretion of nerve growth factor (NGF) required for myelin repair. ${ }^{21}$ Sensory nerve regeneration is faster because it has $>1$ Schwann cell. In contrast, motor nerves regenerate more slowly because it is a myelinated nerve type with a larger axon size with only one Schwan cell. ${ }^{22}$ Thus, folic acid levels are more significant in motor nerves when compared to sensory nerves.

Folic acid and cobalamin have an essential role in maintaining peripheral nerves. The two vitamins work together and are closely related. Cobalamin is a cofactor that plays an essential role in the folate cycle by converting N5-methylenetetrahydrofolate (N5-methylene-THF) into the active form of folate, tetrahydrofolate (THF). When cobalamin deficiency occurs, folate will be trapped in the form of $\mathrm{N}_{5}$-methylene-THF, which is known as "folate trapping". ${ }^{11}$

Folic acid and cobalamin play a role in the homocysteine metabolism process, which is an amino acid. The methionine metabolism may become toxic when it takes reactive oxygen species (ROS) that can cause nerve damage, especially in myelin. ${ }^{23}$ Cobalamin deficiency is established by examining a low serum cobalamin level of $<200 \mathrm{ng} / \mathrm{mL}$. Cobalamin levels in the subjects of this study were within normal limits. They were not associated with the presence of peripheral neuropathy nor the number of affected nerve fibers on NCS examination. A previous study by Asma et al. ${ }^{18}$ on 157 beta-thalassemia patients demonstrated that $28.6 \%$ of these patients experienced cobalamin deficiency.

This study did not include examinations of the levels of other $B$ vitamins such as vitamins $\mathrm{B} 1$ and B6, which also play a role in peripheral neuropathy.

\section{Conclusions}

No relationship between folic acid level, cobalamin level, and peripheral neuropathy was identified in children with beta-thalassemia major in this study. However, there is a relationship between 
folic acid level and the number of motor nerves affected based on the NCS examination.

\section{Conflict of Interest}

All authors declare no conflict of interest.

\section{Acknowledgment}

We would like to thank all the staff of Dr. Hasan Sadikin General Hospital, especially the staff of Thalassemia Clinic.

\section{References}

1. Scellack G, Harirari P, Schellack N. B-complex vitamin deficiency and supplementation. S Afr Pharm J. 2015;82(4):28-33.

2. Hammond $\mathrm{N}$, Wang $\mathrm{Y}$, Dimachkie MM, Barohn RJ. Nutritional neuropaties. Neurol Clin. 2013;31(2):477-89.

3. Higgs DR, Engel JD, Stamatoyannopoulos G. Thalassaemia. Lancet. 2012;379(9813):37383.

4. RSUP Dr. Hasan Sadikin. WHO: 6-10\% masyarakat Indonesia memiliki keturunan thalassemia [Internet]. Bandung: RSUP Dr. Hasan Sadikin; 2014 April 22 [cited 2021 May 6]. Available from: https://web.rshs.or.id/ who-6-10-masyarakat-indonesia-memilikiketurunan-thalassemia.

5. Panigoro R, Rakhmila LE, Sribudiani $\mathrm{Y}$, Maskoen AM, Tjandraprawira KD. Thalassemia in Indonesia: screening program, diagnosis and research. Hemoglobin. 2019;43(6):305.

6. Bayhan $\mathrm{T}$, Ünal Ş, Konuşkan $\mathrm{B}$, Erdem $\mathrm{O}$, Karabulut E, Gümrük F. Assessment of peripheral neuropathy in patients with $\beta$-thalassemia via electrophysiological study: reevaluation in the era of iron chelators. Hemoglobin. 2018;42(2):113-6.

7. Shah FH, Idrees J, Ali Shah ST, Khan R, Khan AT, Salman S, et al. Neurological deficits among beta-thalassemia patients and its possible therapeutic intervention: a comprehensive review. J Dow Univ Health Sci. 2020;14(2):83-90.

8. Oliveros $\mathrm{O}$, Trachtenberg $\mathrm{F}$, Haines $\mathrm{D}$, Gerstenberger E, Martin M,Carson S, etal.Pain over time and its effects on life in thalassemia. Am J Hematol. 2013;88(11):939-43.

9. Dewi WKK, Gamayani U, Lailiyya N, Reniati
L, Sekarwana N. Hubungan kadar hemoglobin dan feritin serum dengan gambaran konduksi saraf pada anak talasemia beta mayor. Neurona. 2017;35(1):52-8.

10. Gamayani U, Putri FA, Lailiyya N, Fianza PI, Panigoro R. Neuropati perifer pada penyandang talasemia di Poliklinik HematoOnkologi RSUP Dr. Hasan Sadikin Bandung. Neurona. 2019;36(3):195-201.

11. Galanello R, Origa R. Beta-thalassemia. Orphanet J Rare Dis. 2010;5:11.

12. Porter J, Viprakasit V, Kattamis A. Iron overload and chelation. In: Cappellini MD, Cohen A, Porter J, Taher A, Viprakasit V, editors. Guidelines for the management of transfusion dependent thalassaemia (TDT). $3^{\text {rd }}$ Edition. Nicosia: Thalassemia International Federation; 2014. p. 42-96.

13. Levi S, Taveggia C. Iron homeostasis in peripheral nervous system, still a black box? Antioxid Redox Signal. 2014;21(4):634-48.

14. Mishra AK, Tiwari A. Iron overload in beta thalassaemia major and intermedia patients. Maedica (Bucur). 2013;8(4):328-32.

15. Heidari M, Gerami SH, Bassett B, Graham RM, Chua AC, Aryal R, et al. Pathological relationships involving iron and myelin may constitute a shared mechanism linking various rare and common brain diseases. Rare Dis. 2016;4(1):e1198458.

16. Bhattacharyya S, Samuels MA. Toxic and metabolic disorders. In: Samuels MA, Ropper AH. Samuel's manual of neurologic therapeutics. $9^{\text {th }}$ Edition. Philadelphia: Wolters Kluwer; 2017. p. 584-633.

17. Patil VW, Mujawar SA. Deficiency of folic acid, vitamin B12 and their correlation with ferritin in childhood $\beta$-thalassemia major. Curr Pediatr Res. 2010;14(2):111-4.

18. Asma S, Gereglioglu C, Erdogan AF, Yeral M, Kasar M, Boga C, et al. Prevalence of iron, folic acid and vitamin B12 deficiency in patients with thalassemia minor. Turk J Fam Med Prim Care. 2013;7(4):83-6.

19. National Center for Biotechnology Information, U.S. National Library of Medicine. Compound summary: folic acid [Internet]. Bethesda: U.S. National Library of Medicine; 2019 January 15 [cited 2021 May 6]. Available from: https://pubchem.ncbi. nlm.nih.gov/compound/135398658.

20. Kang WB, Chen YJ, Lu DY, Yan JZ. Folic acid contributes to peripheral nerve injury repair 
164 Uni Gamayani et al.: Relationship between Vitamin B9 (Folic Acid), Vitamin B12 (Cobalamin), and Peripheral Neuropathy

by promoting Schwann cell proliferation, migration, and secretion of nerve growth factor. Neural Regen Res. 2019;14(1):132-9.

21. Kim GB, Chen Y, Kang W, Guo J, Payne R, Li $\mathrm{H}$, et al. The critical chemical and mechanical regulation of folic acid on neural engineering. Biomaterials. 2018;178:504-16.

22. Fallon M, Tadi P. Histology, Schwann cells
[Internet]. Treasure Island: Statpearls Publishing; 2021 May 10 [cited 2021 June 10]. Available from: https://www.statpearls. com/ArticleLibrary/viewarticle/28765.

23. Mahmood L. The metabolic processes of folic acid and vitamin B12 deficiency. J Health Res Rev. 2014;1(1):5-9. 